TITLE PAGE

Title Electricity in Central America: paradigms, reforms and the energy trilemma

Authors Danielle Gent ${ }^{1}$ and Julia Tomei ${ }^{2 *}$

Affiliations $\quad{ }^{1}$ Department of Geography, Loughborough University, Leicestershire, LE11 3TU, UK. dani_gent@hotmail.com

2 UCL-Energy, University College London, Central House, 14 Upper Woburn Place, London WC1H ONN, UK. j.tomei@ucl.ac.uk

* Corresponding author

UCL-Energy, University College London, Central House, 14 Upper Woburn Place, London WC1H ONN, UK.

[e] j.tomei@ucl.ac.uk

[t] 02031085992 


\title{
Electricity in Central America: paradigms, reforms and the energy trilemma
}

\begin{abstract}
A new global energy era is emerging, one driven by the confluence of energy security, climate politics and energy equity issues. This 'energy trilemma' is shaping the global political economy of energy, which in turn influences how decisions are made about how energy is provided - referred to as global energy governance. This paper analyses historical and contemporary developments in Central America's power sectors. This is a region that has long been an implementation space for global policy priorities, but has been overlooked by those engaging with the challenges of the energy trilemma. During the 1990s and 2000s, the statist model of energy governance gave way to a market-led model in the Central American isthmus. This led to the privatisation of state-owned utilities and the promotion of a regional electricity market. During this period, the dominance of largely hydro-based renewable electricity generation diminished to be replaced by imported fossilbased generation. Oil price increases during the early 2000s highlighted the region's dependence on imports, with some countries turning to energy rationing. Increasingly interventionist state policies, which now seek to reduce oil dependence, improve energy efficiency and expand access to electricity, are being pursued in the region. This interventionist turn reflects the pressures of the energy trilemma, although energy security, particularly the need to reduce dependence on imported oil, remains the most important driver.
\end{abstract}

Keywords: Central America; energy paradigms; energy trilemma; electricity. 


\section{Introduction}

Over recent years a new energy era has been emerging, one which sees the confluence of three global policy drivers: energy security, climate politics and energy poverty - referred to as the energy trilemma (Gunningham, 2013). These drivers define the current global political economy of energy, which is characterised by increasing complexity, path dependency and embeddedness in international policy fields (Goldthau and Sovacool, 2012). While energy policy agendas have typically been dominated by concerns for energy security, this agenda has been complemented by recognition of the central role of energy in climate change mitigation. Recent years have also witnessed the re-interpretation of long standing social concerns, such as poverty alleviation, in ways that place energy at their core. UN Secretary General Ban Ki-moon described sustainable energy as 'the golden thread that weaves together economy, environment and equity' (UN, 2012). 2015 was an important agenda-setting year - with the global community converging on two agreements likely to determine the policy frameworks for sustainable energy for the coming decades: the 2030 Agenda for Sustainable Development and the Paris Agreement on climate change.

Goldthau (2012) uses the concept of 'energy paradigms' to analyse shifts in national and international energy policies and governance over time. He argues that energy paradigms have shifted to reflect wider economic paradigm change, thus the shift from statism to neo-liberalism over recent decades. Most recently, we see a shift to a hybrid state-market model, which Goldthau labels 'interventionist'. This interventionist paradigm has emerged in response to the energy trilemma, which requires those governing energy to deliver on a much more complex set of issues than previously. The interventionist paradigm is one in which energy is viewed as having strategic qualities in several critical policy fields, and has arisen in response to the recognition that the market alone cannot deliver more normative energy goals. Many scholars argue that current modes of energy governance are unable to match the nature and scope of the challenges presented by the energy trilemma (e.g. Florini and Sovacool, 2009; Cherp et al., 2011; Goldthau and Sovacool, 2012). Indeed, Bradshaw (2010, p.275) reminds us of the gravity of these challenges, which demand 'a low carbon energy revolution on a scale beyond the first industrial revolution in a much shorter time frame'. Further, Cherp et al. (2011) argue that such a transformation will need to mobilise unprecedented resources, overcome systemic inertia, and ensure temporal and scalar coordination across energy sectors, including with non-energy sectors. These challenges will require new governance arrangements that enable coordination between national governments, private sector actors, civil society and multilateral organisations.

For Goldthau, 'paradigms are inextricably linked to rule-setting power' $(2012$, p.204). In other words, it is the rule-makers (i.e. industrialised OECD countries and, increasingly, emerging economic powers such as China and India) who determine the field for the rule-takers (i.e. developing, nonOECD countries). According to this framework, the ability of rule-takers to forge their own energy pathways is conditioned by their relative power in the global political economy. However, the key transmitters and enforcers of these 'rules' are not elaborated within the framework. There have been several papers that explore the energy trilemma from the perspective of so called rule-makers, including Goldthau's 2012 paper that provides the framework for this analysis (see also Dubash, 2011; Kong, 2011; La Viña et al., 2011). However, there have been far fewer publications that focus on the consequences of energy paradigm shifts for rule-takers. Therefore in this paper, we focus on 
one 'rule-taking' region, Central America, to trace the drivers and outcomes of historical and contemporary shifts in global energy governance, and to investigate whether there is evidence for a shift to an interventionist paradigm.

There are relatively few publications on recent transitions and energy challenges in Central America, particularly considered within their wider social and political-economic contexts. Several academics have investigated the impacts of electricity privatisation in individual states (see, for example, Julie Cupples (2011) on Nicaragua, and Wilfredo Flores (2012) on Honduras). However, at the regional level, while the UN Economic Commission for Latin America and the Caribbean (CEPAL) provides comprehensive and up-to-date energy statistics, previous research has focused on techno-economic analyses (e.g. Hosier et al., 1992; Apergis and Payne, 2009a, 2009b, 2011; Meza, 2014), and/ or the implications of reforms, albeit from the perspective of the international financial institutions (IFIs) (e.g. Tomiak and Millán, 2002; Millán, 2007; Lecaros et al., 2010; Cayo, 2011; Reinstein et al., 2011). The transnationalisation of the energy sector has had far reaching consequences for the political economies of the Central American states, yet these impacts have been under-researched. The lack of research is perhaps surprising given that as global debates focus on decarbonising energy sectors, until fairly recently Central America was undergoing a paradoxical transition away from renewable electricity generation to increased dependency on fossil generation which has only recently begun to be reversed. This transition is also paradoxical since not only are the countries of Central America highly vulnerable to climate change (Harmeling and Eckstein, 2012), but they are also among the most favourable locations in Latin America for investment in renewable energy (IDB, 2015). We argue that Central America provides an important case study through which to examine shifting energy paradigms.

This paper analyses the Central American electricity sectors through the lens of global energy paradigms. It draws on the academic and grey literature, and is further informed by interviews conducted with a range of stakeholders, which traced the evolution of Central American energy sectors. The paper begins with an introduction to the political economy of the region and outlines the key energy challenges faced by the region. It then examines the outcomes of shifting energy paradigms for the electricity sectors, before moving on to discuss the apparent energy transitions underway across the region. 


\section{Central America and its energy challenges}

Located on a narrow strip of land between North and South America, Central America (Figure 1) is a relatively small region with a total land area of 49 million hectares. The six states ${ }^{1}$ have many commonalities, sharing a language, cultures and histories. The region is also characterised by inequality and poverty. Even in Costa Rica, which has the region's highest GDP per capita, around $20 \%$ of the population live below the poverty line (CEPAL 2011).

Figure 1. Map of Central America

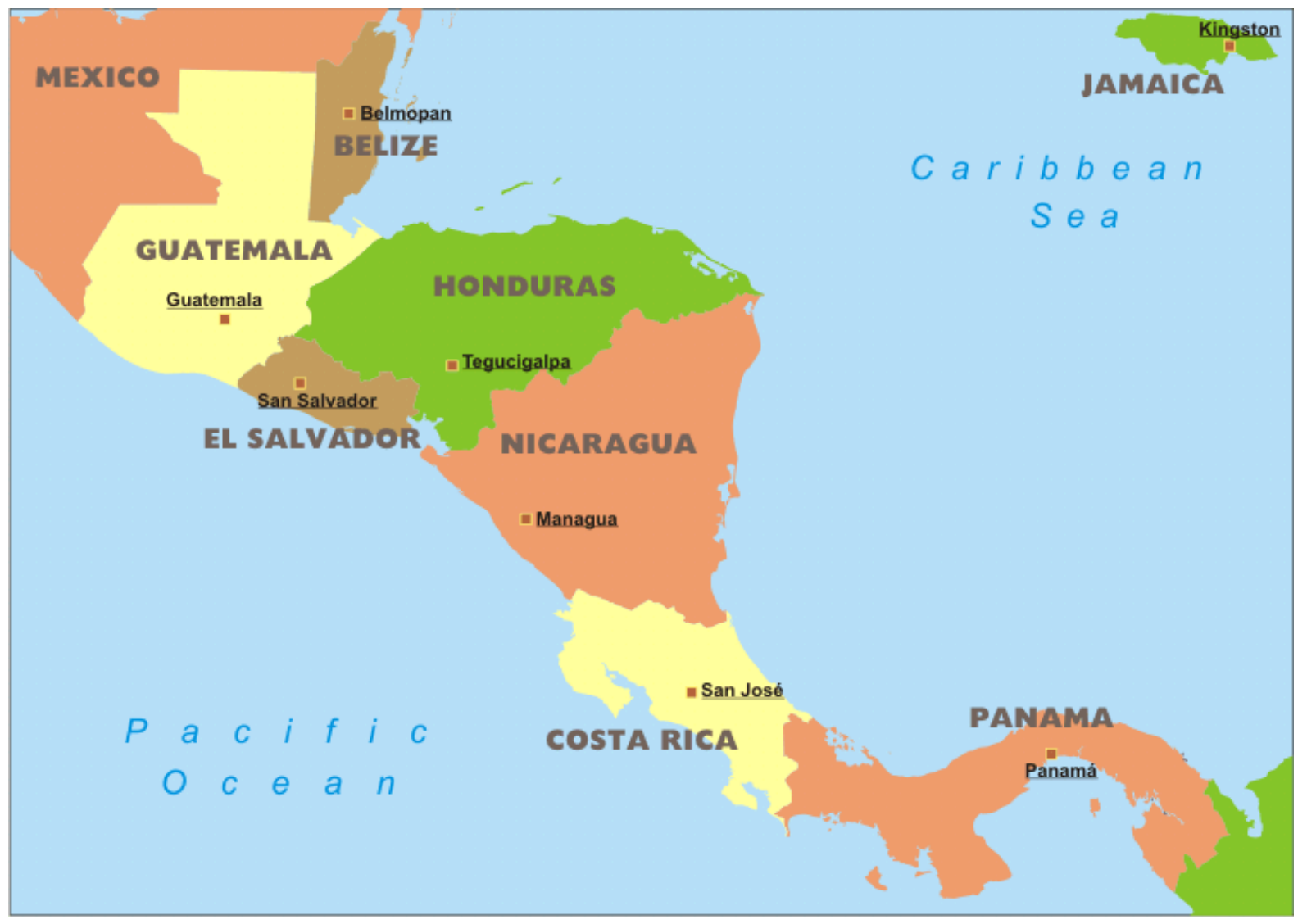

Source: freeworldmaps.net

Demographic changes, including population growth, increasing urbanisation, and better economic conditions have contributed to increased demand for electricity. Since 1990 regional maximum electricity demand has more than doubled, reaching 7,825 MW in 2014 (CEPAL, 2015). Over the same period, installed capacity more than trebled (see Table 1). Electricity coverage has also increased significantly since 1990 , rising from $57 \%$ of the population to $90 \%$ by 2013 ; although, as shown in Table 1, electrification rates vary significantly between and within countries. For example, some urban areas in Guatemala, Honduras and Nicaragua have coverage rates of up to $90 \%$, while more isolated rural areas may have as little as $20 \%$ electricity access (CEPAL, 2008). Although

\footnotetext{
${ }^{1}$ The six countries of Central America are Costa Rica, El Salvador, Guatemala, Honduras, Nicaragua, and Panama. Although Belize is located in the Central American isthmus, as an English-speaking former British colony, it has a distinct history from the other countries in the region. In this paper we consider it to be separate.
} 
electrification has increased, electrification levels alone hide significant distributional inequities relating to ability to pay as well as quality and sustainability of supply. The region's real energy matrix remains dominated by the use of traditional biomass.

Table 1. Evolution of the Central American electricity sectors, demand and electricity coverage 1990 to 2014.

\begin{tabular}{lccccccccc}
\hline Country & Maximum demand (MW) & \multicolumn{2}{c}{ Installed capacity } & \multicolumn{2}{c}{$\begin{array}{c}\text { Net generation } \\
\text { (MW) }\end{array}$} & \multicolumn{3}{c}{$\begin{array}{c}\text { Electricity coverage } \\
\text { (GW) }\end{array}$} \\
& $\mathbf{1 9 9 0}$ & $\mathbf{2 0 1 4}$ & $\mathbf{1 9 9 0}$ & $\mathbf{2 0 1 4}$ & $\mathbf{1 9 9 0}$ & $\mathbf{2 0 1 4}$ & $\mathbf{1 9 9 0}$ & $\mathbf{2 0 1 3}$ \\
\hline CR & 682 & 1632 & 887 & 2885 & 3543 & 10118 & 91 & 100 \\
ES & 412 & 1035 & 650 & 1584 & 2164 & 5877 & $77 *$ & 94 \\
GU & 452 & 1636 & 811 & 3134 & 2318 & 9781 & 36 & 90 \\
HO & 351 & 1383 & 533 & 1940 & 2274 & 7789 & 39 & 89 \\
NI & 253 & 636 & 363 & 1312 & 1251 & 4000 & 45 & 91 \\
PA & 464 & 1504 & 883 & 2813 & 2709 & 9190 & 73 & 76 \\
\hline C. America & $\mathbf{2 6 1 4}$ & $\mathbf{7 8 2 5}$ & $\mathbf{4 1 2 7}$ & $\mathbf{1 3 6 6 7}$ & $\mathbf{1 4 2 5 9}$ & $\mathbf{4 6 7 5 5}$ & $\mathbf{5 7}$ & $\mathbf{9 0}$ \\
\hline
\end{tabular}

$\mathrm{CR}=$ Costa Rica; $\mathrm{ES}$ = El Salvador; GU = Guatemala; $\mathrm{HO}=$ Honduras; $\mathrm{NI}$ = Nicaragua; PA = Panamá. Note: Net generation in three countries (GU, NI and PA) appear to be greater than installed capacity. This may be due to reporting errors or unreported off-grid generation capacity. *Data for 1995. Sources: CEPAL (2009, 2011, 2015); IEA World Energy Outlook (2015)

Whilst there are differences between the electricity sectors of the six Central American states, they also face similar challenges. Firstly, the region's electricity markets are relatively small. In 2010, the region generated approximately $40 \mathrm{TWh}$ of electricity, which is equivalent to around $70 \%$ of the annual electricity supply of a medium-sized Latin American country, such as Chile or Colombia (Lecaros et al., 2010). Small markets do not provide a sufficiently large demand base to support competition in generation. This carries the risk of the sector being dominated by one or two players, therefore inhibiting competition. Secondly, several countries in the region have faced challenges in balancing supply and demand, at times leading to supply deficits and rationing (Posas, 1995; World Bank, 2006; Cupples, 2011). This has been most acute in Honduras and Nicaragua, which have historically been prone to power shortages and rationing. Continued economic growth means that regional energy demand continues to rise and there is an urgent need for the six countries to continue to expand their electricity generation capacity. Thirdly, increased private sector participation in electricity generation has led to an increasing reliance on imported fossil fuels. As a result, the region is highly vulnerable to volatility in global oil markets and when the price of oil is high, the region's economies suffer. Fourthly, popular protests against the development of so-called megaprojects, particularly hydroelectric power and biofuels, are common. Historically, such projects have been developed without local consultation, and have particularly affected indigenous groups (e.g. in Panama, Guatemala and Honduras); authorities have often responded to resultant protests with violent repression. Finally, despite increased electricity access, of the 43 million people in Central America, an estimated seven million still do not have access, while around 20 million rely on firewood to satisfy their most basic energy needs (CEPAL, 2008; Dolezal et al., 2013). National governments have typically viewed the alleviation of energy poverty as synonymous with the expansion of electricity grids. However, the reliance on traditional biomass, and the remote location of many communities, means that meeting the energy needs of the region's population is unlikely to be satisfied through grid expansion alone. 
Despite these considerable challenges, there are a number of opportunities - not least the region's impressive renewable energy resource potential, particularly due to abundant hydroelectricity, geothermal and solar resources (see Table 2). Although renewable energy accounts for $60 \%$ of the electricity generated in the region (CEPAL, 2015), since the 1990s the share of renewables has fallen, reflecting the decline of investment in hydroelectricity; more recently, this is beginning to be offset by increases in other renewable energy investments. Dolezal et al. (2013) argue that, given the development and implementation of appropriate policies, Central America has the potential to meet all of its electricity demand from renewables. Yet, the Central American states have not always been able to exploit these resources. Another opportunity for the region is the creation of a common electricity market, which would mitigate the challenge of each country's small market size. Since the late 1990s, various treaties have been signed to integrate the six countries' electricity markets, and in June 2013 the interconnected electricity grid, SIEPAC (Sistema de Interconexión de Eléctrica de los Países de América Central), became a reality.

Table 2. Estimated renewable energy potential, installed capacity and percentage renewable energy exploited in Central America, 2011.

\begin{tabular}{lrrrrrr}
\hline Country & $\begin{array}{c}\text { Max potential } \\
\text { (MW) }\end{array}$ & $\begin{array}{c}\text { Hydro } \\
\text { Installed } \\
\text { capacity (MW) }\end{array}$ & \% exploited & $\begin{array}{c}\text { Max potential } \\
\text { (MW) }\end{array}$ & $\begin{array}{c}\text { Geothermal } \\
\text { Installed } \\
\text { capacity (MW) }\end{array}$ & \% exploited \\
\hline CR & 5,802 & 1834 & 31.6 & 235 & 218 & 92.8 \\
ES & 2,165 & 488 & 22.5 & 333 & 204 & 61.3 \\
GU & 5,000 & 1033 & 20.7 & 1,000 & 49 & 4.9 \\
HO & 5,000 & 624 & 12.5 & 120 & 0 & 0 \\
NI & 1,760 & 120 & 6.8 & 1,200 & 155 & 12.9 \\
PA & 2,341 & 1623 & 69.2 & 40 & 0 & 0 \\
\hline C. America & $\mathbf{2 2 , 0 6 8}$ & $\mathbf{5 7 2 2}$ & $\mathbf{2 5 . 9}$ & $\mathbf{2 9 2 8}$ & $\mathbf{6 2 6}$ & $\mathbf{2 1 . 4}$ \\
\hline
\end{tabular}

CR = Costa Rica; ES = El Salvador; GU = Guatemala; HO = Honduras; NI = Nicaragua; PA = Panamá. Source: adapted from data in CEPAL $(2009,2012,2015)$

Recent events in Central American electricity sectors suggest that state actors, in partnership with IFIs and the private sector, are seeking to address Central America's energy challenges. In order to understand the motivations behind this apparent interventionist turn, this paper first turns to an examination of the historical political economy of the region's electricity sectors.

\section{Shifting energy governance: from state to market}

Until the 1960s, the generation and distribution of electricity in Central America was dominated by the private sector, with only minimal government participation. Access to electricity was restricted, reaching between just $12-20 \%$ of the population, and largely limited to urban areas (World Bank, 2001; Batlle et al., 2010). From the 1960s to the 1990s, much of Central America experienced social and political upheaval as revolutions met with counter-insurgencies. State involvement in the energy sector increased during the 1960s and 70s, with efforts focused on expanding electricity coverage, mostly focused on urban areas. Following the oil crises of the 1970s, Central American states sought to reduce dependence on oil for electricity generation. The share of oil declined from $50 \%$ in 1970 to $27 \%$ by 1985 (Solá Monserrat, 1989), and was mainly substituted by hydroelectric power often with negative impacts on local people and environments (see Johnston, 2005). 
Following increased state involvement in the region's electricity sectors during the 1970s and 1980s, by the late 1980s electricity utilities were in need of investment. Armed conflict, high supply losses, rising demand for electricity, inadequate tariff policies, and the need to keep pace with economic growth resulted in the decision to privatise electricity utilities. Shifting ownership and operation was expected to result in greater efficiency, lower costs and improved access (Barnes and Waddle, 2004; Rufatt, 2005). Throughout the 1990s, neoliberal reforms led to structural changes in most of the Central American power sectors. These included the privatisation of state-owned generation plants, transmission and distribution companies, and the establishment of regulatory bodies responsible for overseeing electricity utilities.

Also during this period the IFIs, particularly the World Bank and the Inter-American Development Bank (IDB), began to rethink their support strategies in the region. The IDB in particular was instrumental in reforming Central American power sectors. Two parallel processes lay at the centre of reforms: the reform of national power sectors, and their subsequent integration into a regional grid (Cayo, 2011). To facilitate this, changes were made to the way in which the IDB supported the region's power sectors with direct support for infrastructure replaced by technical and financial support vehicles that would assist the implementation of sectoral reforms, enhancing efficiency, and attracting private capital (Rufatt, 2005). As a result, lending to the public utilities fell dramatically, while lending to private investors increased (Cupples, 2011).

In the five countries that underwent structural reforms, electricity sectors were unbundled and experienced a shift from public to private ownership. Once this took place, a common practice was to sell generation plant which was often followed by the sale of shares in distribution companies. While the level of competition increased overall, in some instances state monopolies were replaced by private monopolies - either by international conglomerates, such as Unión Fenosa in Nicaragua and Guatemala and Distribuidora de Electricidad del Sur in El Salvador, or by national elites (Barnes and Waddle, 2004; Cupples, 2011). In Honduras, the reforms to the sector that were enacted in the 1990s to separate policy, regulation and service, were not fully completed, leaving the utility as a vertically integrated state owned enterprise (Flores, 2012). For Honduras and Nicaragua, privatisation of state-owned electricity utilities was a condition of admission to the Heavily Indebted Poor Countries Initiative (HIPC) (Cupples, 2011). Only Costa Rica imposed restrictions on private investment in generation and the Instituto Costariccense de Electricidad remains a state-run, vertically integrated company (see Meza, 2014 for more detailed description of each country's electricity sectors). Table 3 outlines the impacts of electricity sector reform on institutional arrangements and ownership in the six Central American states. 
Table 3. Electricity sector reform in Central America: institutional arrangements and shifts in ownership

\begin{tabular}{|c|c|c|c|c|c|c|c|c|}
\hline \multirow{2}{*}{ Country } & \multirow{2}{*}{$\begin{array}{l}\text { Year of } \\
\text { reform }\end{array}$} & \multirow{2}{*}{$\begin{array}{l}\text { Institutional } \\
\text { arrangements }\end{array}$} & \multicolumn{6}{|c|}{ Net private ownership of electricity generation (\%) } \\
\hline & & & 1990 & 1995 & 2000 & 2005 & 2010 & 2014 \\
\hline $\mathrm{CR}$ & 1995 & Integrated & 0 & 1.6 & 16.3 & 13.1 & 19.8 & 17.6 \\
\hline ES & 1997 & Retail competition & 0 & 6.1 & 43.7 & 66.3 & 64.6 & 71.0 \\
\hline GU & 1998 & $\begin{array}{l}\text { Wholesale } \\
\text { competition }\end{array}$ & 0 & 32.3 & 58.7 & 70.0 & 69.9 & 74.3 \\
\hline $\mathrm{HO}$ & 1994 & Integrated & 0 & 31.6 & 39.5 & 70.6 & 62.7 & 75.3 \\
\hline $\mathrm{NI}$ & 2000 & $\begin{array}{l}\text { Wholesale } \\
\text { competition }\end{array}$ & 0 & 0.6 & 55 & 77.6 & 80.5 & 91.0 \\
\hline PA & 1998 & $\begin{array}{l}\text { Wholesale } \\
\text { competition }\end{array}$ & 3.1 & 3.8 & 100 & 89.3 & 88.2 & 85.6 \\
\hline C. America & & & 0.6 & 12.4 & 50.4 & 68.4 & 59.8 & 65.4 \\
\hline
\end{tabular}

The transition from state-led to market-led governance had a considerable impact on the way in which electricity generation, transmission and distribution networks operated. While it is not the aim of this paper to discuss whether these reforms were appropriate to the Central American context, it is important to outline some of the key impacts and their contribution to the region's current energy challenges.

\subsection{From hydro to fossil fuel based generation}

Following structural reforms, the region's electricity generating mix underwent a significant shift (see Figure 2). In particular, we observe a decline in the share of renewable energy generation, specifically hydropower (although this has been partially offset by other renewable energy generation coming online more recently) - while dependence on imported fossil fuels increased (Lecaros et al., 2010; Reinstein et al., 2011; CEPAL, 2011, 2015). Fossil-based generation presented lower risks for private investors than renewable electricity generation due to shorter lead times and lower upfront costs. However, this also locked the Central American economies into higher costs in the longer term due to reliance on imported fossil fuels and exposure to international price volatility. Between 1990 and 2002, oil use for electricity generation grew annually by an average of 19\%. While in 1990, Central America's oil bill amounted to US\$ 47 million, by 2002 it had increased to US\$ 444 million (CEPAL, 2003). Increased reliance on imported fossil fuels had even greater financial consequences when international prices rose sharply between 2005 and 2007 (Lecaros et al., 2010). Accordingly, Central America has experienced amongst the highest electricity costs in the Western Hemisphere (Trinkunas, 2014), although more recent lower oil prices have alleviated this somewhat. 
Figure 2. Percentage share of net electrical generation by source, 1990- 2014.

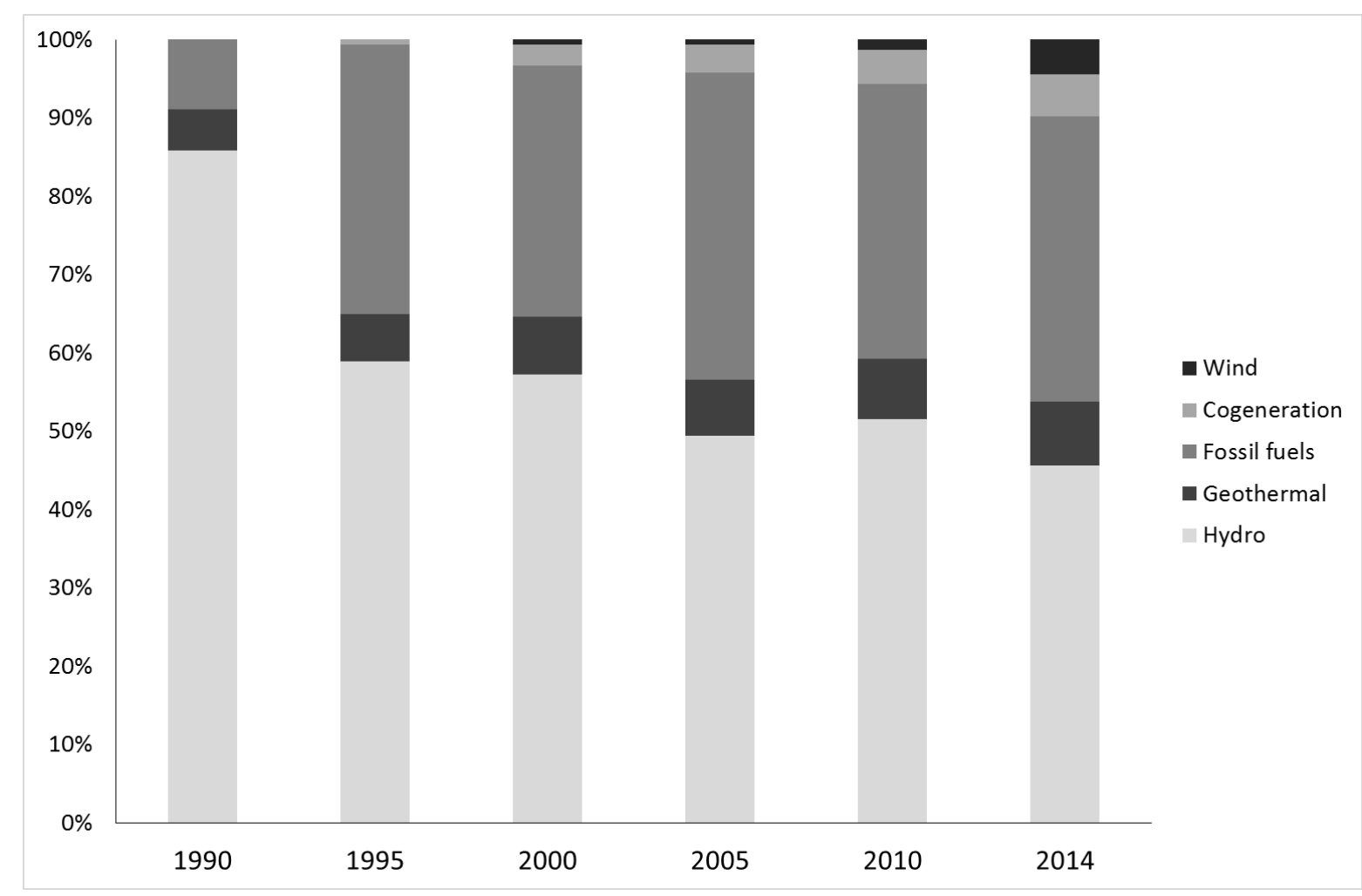

Source: adapted from CEPAL $(2012,2015)$

The Central American energy landscape has also been strongly influenced by broader Latin American developments. For example since its establishment in 2001, several Central American states ${ }^{2}$ have joined Petrocaribe, a regional oil alliance with Venezuela. Established by Hugo Chávez to reduce the impacts of high oil prices in Central America and the Caribbean, Petrocaribe offers its members subsidised oil financing. Trinkunas (2014) argues that Petrocaribe has led to rising levels of debts owed to Venezuela, and had the potential to create disincentives for the adoption of new technologies and investment in renewable energy.

\subsection{Electricity access}

The outcomes of the reform process for access to electricity have been uncertain. As shown in Table 1 , the regional average of electrical coverage improved, reaching 90\% of the population by 2014 . Guatemala, Honduras and Nicaragua - the three countries with the lowest proportion of electricity access in 1990 - have increased electrical coverage from around 40\% to between $75-85 \%$ in 2010. Barnes and Waddle (2004) argue that the historically poor performance of state utilities in rural areas meant that private investors were reluctant to invest in projects away from key urban markets. As a result, while private investors were effective in connecting consumers in urban and rural areas near to the power grid, the needs of those living outside more 'profitable' areas of service were neglected. Privatisation did not relieve the state of responsibility for rural electrification, as had

\footnotetext{
2 Nicaragua joined in 2007, Guatemala and Honduras in 2008, and El Salvador in 2012. Guatemala left in 2013 citing changes in financial terms. Honduras' membership was suspended in 2009 after the overthrow of the Zelaya government, but the country was invited to re-join Petrocaribe in 2014.
} 
been expected. Rather, the provision of electricity to poorer rural areas has come about as a result of state intervention (Barnes and Waddle, 2004). However, despite improvements, electrification remains limited in rural areas, particularly where demand, population density and incomes are low.

\subsection{Regional electricity integration}

Electricity integration has been another focus of IFI involvement in the region. During the 1990s, frequent supply crises (triggered by high growth in demand), low reserve margins, oil price hikes, climatic events (particularly droughts), and delays in the construction of new generation, galvanised efforts to create a regional energy market (MER, or Mercado Eléctrico Regional) and regulatory system. At the centre of these efforts has been the development of an interconnected electricity grid, SIEPAC. Potential benefits included enhanced competition, secure electricity supplies where generation deficits existed, and greater reliability, efficiency and lower costs due to economies of scale (Lecaros et al., 2010). Incremental progress was made during the 1990s and 2000s, and it was not until June 2013 that the 1,800 kilometre electric transmission was completed and the MER entered into effect. While it is expected that SIEPAC will also be connected to Mexico and Colombia in the future, political issues, contrasting regulatory regimes, security concerns and local conflicts continue to present challenges to the MER and the magnitude of electricity transactions across national borders remains relatively low (Martin and Posadas, 2012; Zarnikau et al. 2013; Trinkunas, 2014).

\section{From the market to an era of intervention?}

The impact of power sector reforms has been variable. Proponents have argued that in most countries, their key objectives were achieved, and resulted in more reliable and efficient electricity sectors (e.g. Barnes and Waddle, 2004). However, other more critical voices have stressed that reforms have frequently not had the desired outcomes, instead resulting in higher electricity prices, a shift from state to private monopolies, widespread consumer opposition, and low distributional equity (Herrera-Montoya, 2005; McGuigan, 2007; Cupples, 2011). The specificities of the relatively small Central American markets and the social, economic and political contexts presented significant challenges to the reform process, which were arguably overlooked by the national authorities and the IFIs implementing them. Two decades after the process of reforms began, the Central American economies are once more faced with a number of energy challenges, some old and some new. There is a renewed focus on electricity access, while the confluence of the energy security and climate change drivers have led to increased attention being paid to the region's ample renewable energy resources. But is there evidence for the re-emergence of the state in the electricity sector and, if there is, what is driving this governance shift?

\subsection{A re-emergence of the state}

Analysis of regional energy policies published over the last few years provides some evidence for an increasingly interventionist model of energy governance in the region. For example, after 17 years of market-led reforms, El Salvador's 2010 energy policy explicitly acknowledged that sectoral reforms weakened the state's capacity to develop long-term energy strategies. It observed that as a consequence, the ability to plan and think holistically about the energy sector had been lost. Thus, 
one of the four objectives of the policy was to re-establish the role of the state in the development of the energy sector (CNE, 2010). Discontent with the privately-led energy model is also evident in the Nicaraguan context, manifested in the part-renationalisation of the private electricity distribution company Disnorte-Dissur (INE, 2009), and an increased focus on 'electricity access without exclusion' (NI-MEM, 2011). Costa Rica (MINAET, 2011) and Guatemala (GU-MEM, 2013) most recent energy policies also emphasise the role of the state in meeting normative energy objectives. These policies represent a shift away from the market-led model of the preceding decades, one that appears to indicate a resurgence of the state in the energy sector.

Costa Rica's recent energy policy states that, owing to the potential for negative environmental impacts, there will be no exploration of hydrocarbon reserves. Rather, the country plans to take advantage of its renewable energy potential (MINAET, 2011). El Salvador is similarly planning to expand renewable electricity generation, including large-scale geothermal, hydroelectric and concentrated solar power, as well as small-scale wind and solar (CNE, 2010). Although Guatemala also plans to diversify the country's energy matrix through the exploitation of renewable energy sources, as the region's only oil producer, it also aims to 'explore and exploit' national hydrocarbon reserves with a view to self-sufficiency (GU-MEM, 2013). The Nicaraguan government is pushing to enact an ambitious overhaul of its energy system, through the transformation of the electricity generating mix, in addition to extending grid electricity to rural areas (NI-MEM, 2011). Honduras, which has historically suffered supply deficits, has plans to construct new electricity generation capacity, including ambitious investments in solar photovoltaic technologies (PV Magazine, 2015). Finally, Panama, historically reliant on hydropower is focusing on significant policies to support wind and solar investments (IDB, 2015). These directions are being solidified and expanded through Intended Nationally Determined Contributions (INDCs) - plans submitted by countries regarding their post-2020 climate actions under the Paris Agreement ${ }^{3}$. Five out of six Central American countries ${ }^{4}$ submitted INDCs, outlining planned activities across multiple sectors, including energy, transportation, forestry, agriculture, livestock and waste management.

Energy policies in each of the Central American states are clearly responding to the challenges of the energy trilemma, although arguably energy security has been the most influential of these. The rising dominance of diesel in the electricity mix over the previous two decades meant that the region until recently faced escalating energy bills, in turn affecting economic development, supply security, and levels of social conflict. This was most acute in the case of Nicaragua, which experienced a severe energy crisis during 2006-2007 that culminated in rolling blackouts, increased electricity prices and contributed to the near collapse of the economy (Cupples, 2011; Gent, 2014). Across the isthmus, reliance on imported oil has therefore dictated that the state take on a more interventionist role in energy governance in order to maintain macroeconomic stability and avert social and energy crises.

\footnotetext{
${ }^{3}$ For more information on INDCs, see the UN Framework Convention on Climate Change's INDC portal: http://www4.unfccc.int/submissions/INDC/Submission\%20Pages/submissions.aspx ${ }^{4}$ Nicaragua declined to submit an INDC. The lead climate envoy argued that Nicaragua could not legitimise a 'failed mechanism' given that the world remained on track for dangerous climate change. See: http://www.climatechangenews.com/2015/11/30/nicaragua-to-defy-un-in-climatepledge-refusal/
} 
Whilst oil dependency and associated cost concerns have been a major driver in shifting policies, the direction of recent initiatives as well as shifts in the global governance of energy and climate change have also been of growing significance. Addressing the energy trilemma has also translated into financial opportunities for governments, civil society and the private sector across the region. Indeed, the concepts of 'clean energy' and 'energy for all' currently resonate with the priorities of IFIs, and have catalysed the flow of grants and concessional finance to support to address Central America's energy challenges. For example, the 2015 Climatescope report, which provides data on the overall funding landscape for renewable energy in Latin America, identifies significant momentum in renewable energy investment in Central America (IDB, 2015). The report finds that between 2009 and 2014, Central America harnessed more than US\$ 8.3 billion in clean energy investment. In addition to increased financial flows, governments also recognise the economic opportunities offered through the potential sale of electricity to the MER. For example, the Costa Rican energy policy states that the regional electricity market will offer not only the opportunity to incorporate the state into a larger market, thus improving its security, but also to sell excess generation - principally from renewable sources - to the regional grid (MINAET, 2011). The Guatemalan energy policy also cites opportunities for power exports, both to the MER and, eventually, to Mexico (GU-MEM, 2013).

\subsection{Energy paradigms and 'rule-takers'}

The preceding discussion suggests that the evolution of Central America's power sectors broadly reflects Goldthau's paradigm framework (Goldthau, 2012). In other words, common to other regions, energy governance in Central America has gradually shifted from statist to neoliberal to increasingly interventionist regimes. However, this analysis has revealed a number of limitations to the energy paradigm framework. Firstly, the capacity of the Central American states to negotiate their energy pathways is conditioned by their relative power in the global political economy. While Goldthau recognises that energy paradigms are linked to 'rule-setting power', the key transmitters and enforcers of 'rules' are not elaborated within the framework. This points to the need for conceptual reworking to improve the applicability of the framework to energy systems within 'rule taking' contexts. A second limitation, one intimately tied to their position as 'rule takers', is the relationship of the Central American states to the major IFIs. The channelling (or withholding) of grants and concessional finance for targeted energy development assistance programmes serves to privilege some technologies, policies and market segments over others (see also Smits and Bush, 2011; Sovacool and Drupady, 2012), impacting on the energy and emission pathways taken. As key vectors of energy policy prescriptions in the isthmus, greater attention needs to be paid to the role of IFls in energy transitions. Finally, other spheres of influence also require attention in the energy paradigm framework. Section 3.1 drew attention to the role of Venezuelan petrodollars in several Central American states; however, declining oil production and the country's economic crisis leave Petrocaribe's members vulnerable to changes in financial terms and supply reliability (Trinkunas, 2014). Other actors have also emerged as important influencers. For instance, both China and Brazil have emerged as important financiers of renewable energy projects in the region. This echoes findings from other studies which conclude that energy assistance is an increasingly important feature of South-South cooperation (Johnson and Power, 2012; Baker et al., 2013). 


\section{Conclusions}

Over time, Central American power sectors have responded to global shifts in energy governance. Thus, we see a transition from the statist 1970s and 1980s, to the neoliberal paradigm of the late 1990s, through to the current more interventionist era. In Central America, this interventionist turn' has coincided with, and been influenced by a shift in global energy policy priorities evidenced through recently agreed global frameworks - frameworks likely to set the political conditions, policy environments and means to expand access to sustainable energy and stimulate low emission development. The rise to global predominance of the energy trilemma has led to energy policy being transformed from being solely seen as an issue of national supply security, to one that encompasses global climate change and human development concerns. Central American governments have adopted a more prominent role in the delivery of normative energy goals, with recent energy policy documents and national plans promoting the uptake of renewable energies and highlighting the importance of energy for human and economic development. The region's renewable energy potential has been noted by IFIs and other global actors, and has already attracted considerable investment. The current policy discourse and the scale of investment indicate progressive steps towards addressing Central America's energy challenges. However, while the climate change and energy poverty policy agendas are important factors at the national and regional level - ones that are certainly influencing the financing landscape - the current transition has also been heavily influenced by macroeconomic stresses brought about by increased dependence on oil, particularly at times of rising international oil prices. Thus, the extent to which an energy transition is underway in the region, one that will lead to a more secure, sustainable and equitable energy landscape, remains to be seen.

\section{References}

Apergis, N. and Payne, J.E. (2009a). Energy consumption and economic growth in Central America: evidence from a panel cointegration and error correction model. Energy Economics 31: 211-216.

Apergis, N. and Payne, J.E. (2009b). $\mathrm{CO}_{2}$ emissions, energy usage and output in Central America. Energy Policy 37: 3282-3286.

Apergis, N. and Payne, J.E. (2011). The renewable energy consumption-growth nexus in Central America. Applied Energy 88: 343-347.

Baker, L., Kirschner, J., Power, M., Bulkeley, H., Smith, A. and Newell, P. (2013) Energy Transitions in the global South: the role of the 'Rising Powers' in Southern Africa, paper presented the Royal Geographical Society (with Institute of British Geographers) Annual Conference, August 28th-30th, London, 2013.

Barnes, D. and Waddle, D. (2004). Power sector reform and the rural poor in Central America, Washington: ESMAP, The World Bank.

Batlle, C., Barroso, L.A. and Pérez-Arriaga, I.J. (2010). The changing role of the state in the expansion of electricity supply in Latin America. Energy Policy, vol. 38, no. 11, pp. 7152-7160. 
Batlle, C., Barroso, L.A. and Pérez-Arriaga, I.J. (2010). The changing role of the state in the expansion of electricity supply in Latin America. Energy Policy 38 (11): 7152-7160.

Bradshaw, M.J (2010). Global energy dilemmas: a geographical perspective. The Geographical Journal 176(4): 275-290

Cayo, J.M. (2011). Power integration in Central America: from hope to mirage? In: Humberto Lopez, J. and Shankar, R. (2011) (eds.) Getting the Most Out of Free Trade Agreements in Central America, ESMAP, The World Bank, Washington D.C.

CEPAL (2003). Evaluación de 10 años de reforma en la industria eléctrica del istmo centroamericano. Naciones Unidas Comisión Económica para América Latina y el Caribe, Ciudad de México.

CEPAL (2008). La energía y las metas del milenio en Guatemala, Honduras y Nicaragua. Naciones Unidas Comisión Económica para América Latina y el Caribe, Ciudad de México

CEPAL (2009). Istmo Centroamericano: las fuentes renovables de energía y el cumplimiento de la Estrategia 2020. Naciones Unidas Comisión Económica para América Latina y el Caribe, Ciudad de México.

CEPAL (2011). Istmo Centroamericano: Estadísticas del subsector eléctrico. Naciones Unidas Comisión Económica para América Latina y el Caribe, Ciudad de México.

CEPAL (2012). Centroamérica: estadísticas de producción del subsector eléctrico, 2011. Naciones Unidas Comisión Económica para América Latina y el Caribe, Ciudad de México.

CEPAL (2015). Centroamérica: estadísticas de producción del subsector eléctrico, 2014. Naciones Unidas Comisión Económica para América Latina y el Caribe, Ciudad de México.

Cherp, A., Jewell, J. and Goldthau, A. (2011). Governing Global Energy: Systems, Transitions, Complexity. Global Policy 2(1): 75-88.

CNE (2010). Política Energética Nacional. Consejo Nacional de Energía, San Salvador. Available from: http://www.cne.gob.sv/index.php?option=com_content\&view=article\&id=153\&ltemid=201 [Accessed March 2013]

Cupples, J. (2011). Shifting networks of power in Nicaragua: relational materialisms in the consumption of privatised electricity. Annals of the Association of American Geographers 101(4): 939-948.

Dolezal, A., Majano, AM., Ochs, A. and Palencia, R. (2013). The way forward for renewable energy in Central America. WorldWatch Institute, Washington D.C.

Dubash, N. (2011). From Norm Taker to Norm Maker? Indian Energy Governance in Global Context. Global Policy 2: 66-79. 
Flores, W.C. (2012). Analysis of regulatory framework of electric power market in Honduras: promising and essential changes. Utilities Policy 20(1): 46-51.

Florini, A. and Sovacool, B.K. (2009). Who governs energy? The challenges facing global energy governance. Energy Policy 37(12): 5239-5248

Gent, D (2014). Governing energy in Nicaragua: the practices and experiences of off-grid solar energy technologies. Unpublished PhD thesis, Loughborough University.

Goldthau, A. (2012). From the state to the market and back: policy implications of changing energy paradigms. Global Policy 3(2): 198- 209.

Goldthau, A. and Sovacool, B. (2012). The uniqueness of the energy security, justice and governance problem. Energy Policy 41: 232-240.

Gunningham, N. (2013) Managing the energy trilemma: the case of Indonesia. Energy Policy, vol. 54, pp. 184-193.

GU-MEM (2013). Política Energética, 2013-2027. Ministerio de Energía y Minas, Guatemala City. Available at: http://www.mem.gob.gt/2013/02/politica-energetica-2013-2027-con-vision-de-pais/ [Accessed March 2013]

Harmeling, S. And Eckstein, D. (2012). Global Climate Risk Index 2013: Who suffers most from extreme weather events? Weather-related loss events in 2011 and 1992 to 2011. Germanwatch Briefing Paper, available from: http://germanwatch.org/fr/download/7170.pdf [Accessed: August 2013].

Herrera-Montoya, R.S (2005). Crisis del sector energético: ¿Nicaragua apagándose? Red Nacional de Defensa de los Consumidores, Managua.

Hosier, R.H., Bernstein, M.A. and Hildebrandt, E. (1992). Energy development, regional cooperation and $\mathrm{CO}_{2}$ emissions in Central America. Energy Policy 20: 297 - 309

IDB (2015). Climatescope 2015: The Clean Energy Country Competitiveness Index. Inter-American Development Bank, Power Africa, DfID, and Bloomberg New Energy Finance, Washington D.C.

IEA (2015). World Energy Outlook 2015: Electricity Access Database. International Energy Agency, Paris. Available from: http://www.worldenergyoutlook.org/resources/energydevelopment/energyaccessdatabase/ [Accessed March 2016].

INE (2009). Decreto De Aprobación Del "Protocolo De Entendimiento Entre Las Empresas Distribuidoras De Electricidad Del Norte, S.A. (Disnorte), Distribuidora De Electricidad Del Sur, S.A. (Dissur), El Grupo Unión Fenosa Internacional S.A., Y El Gobierno De La República De Nicaragua". Decreto No. 5557. Aprobado el 12 de febrero de 2009, Publicados en las Gacetas Nos. 49, 50 y 51 del 12, 13 y 16 de marzo de 2009, Available from: 
November 2012].

Johnson, P.H. and Power, M. (2012) 'The Rising Powers and South-South co-operation for low carbon development', paper presented at the Royal Geographical Society (with Institute of British Geographers) Annual Conference, University of Edinburgh, July $3^{\text {rd }}-5^{\text {th }}, 2012$.

Johnston, B.R. (2005). Volume One: Chixoy Dam Legacy Issues Study, Executive Summary: Consequential Damages and Reparation: Recommendations for Remedy, Center for Political Ecology, California.

Kong, B. (2011). Governing China's Energy in the Context of Global Governance. Global Policy 2: 5156.

La Viña, A.G.M., Dulce, J.C. and Saño, N. (2011). National and Global Energy Governance: Issues, Linkages and Challenges in the Philippines. Global Policy 2: 80-93.

Lecaros, F., Cayo, J. and Dussan, M. (2010). Estudio programático regional para el sector energético de América Central: aspectos generales y opciones. Departamento de Desarrollo Sostenible Región de América Latina y el Caribe. Available from: www.sica.int/ [Accessed December 2012]

Martin, J.M. and Posadas, J.C. (2012). Central America's electric sector: the path to interconnection and a regional market. Journal of Energy Security, July 2012.

McGuigan, C. (2007). The impact of World Bank and IMF conditionality: an investigation into electricity privatisation in Nicaragua. Christian Aid, London.

Meza, C. (2014). A review on the Central America electrical energy scenario. Renewable and Sustainable Energy Review 33: 566-577.

Millán, J. (2007). Market or State? Three decades of reform in the Latin American Electric Power Industry. Inter-American Development Bank, Washington D.C.

MINAET (2011). VI Plan Nacional de Energía, 2012 - 2030. Ministerio de Ambiente, Energía y Telecomunicaciones, San José. Available from: http://www.dse.go.cr/es/03Publicaciones/01PoliticaEnerg/VI_Plan_Nacional_de_Energia_20122030.pdf [Accessed March 2013]

NI-MEM (2011). Aporte del Ministerio de Energía y Minas al desarrollo socioeconómico de Nicaragua. Ministerio de Energía y Minas, Managua.

Posas, M. (1995). Now There is Light but Blackouts Continue. Revista Envío, No. 163, February 1995, Central American University (UCA), Managua. 
PV Magazine (2015). Entraron en servicio 389 MW solares en Honduras en lo que va de año. PV Magazine, available from: http://www.pv-magazine-latam.com/noticias/detalles/articulo/entraronen-servicio-389-mw-solares-en-honduras-en-lo-que-va-de-ao_100021142/ [Accessed April 2016].

Reinstein, D., Mateos, A., Brugman, A., Johnson, T. and Berman, L. (2011). Regional Power integration: Structural and regulatory challenges: Central America Regional Programmatic Study for the Energy Sector. ESMAP, The World Bank, Washington D.C.

Rufatt, A. (2005). Reforms in basic infrastructure. In: Large, W.R. (2005). An enduring partnership for development: Central America and the IDB since 1990. Inter-American Development Bank. Washington D.C.

Smits, M. and Bush, S.R. (2010). A light left in the dark: The practice and politics of pico-hydropower in the Lao PDR. Energy Policy 38 (1): 116-127.

Solá Monserrat, R. (1989). Geografía y estructura económicas de Nicaragua en el contexto centroamericano y de América Latina. Facultad de Ciencias Económicas y Administrativas, Universidad Centroamericana, Managua.

Sovacool, B.K. and Drupady, I.M. (2012). Energy access, poverty and development, Ashgate, New York.

Tomiak, R. and Millán, J. (2002). Sustainability of Reform in Central America: Market Convergence and Regional Integration. Inter-American Development Bank, New York. Available from: http://idbdocs.iadb.org/wsdocs/getdocument.aspx?docnum=1441598 [Accessed June 2010]

Trinkunas, H. (2014). Changing energy dynamics in the Western Hemisphere: impacts on Central America and the Caribbean. Latin America Initiative, Foreign Policy at Brookings. Available from: http://www.brookings.edu/ /media/research/files/papers/2014/04/04\%20energy\%20central\%20a merica\%20trinkunas/changing\%20energy\%20dynamics.pdf [Accessed August 2014].

United Nations (2012). At Rio Event, Secretary-General Says 'Sustainable Energy is the Golden Thread' That Weaves Together Economy, Environment, and Equity, UN Secretary-General, SG/SM/14363,ENV/DEV/1298. Available from: http://www.un.org/News/Press/docs/2012/sgsm14363.doc.htm [Accessed April 2013]

World Bank (2001). Nicaragua: Sustainable off-grid electricity service delivery mechanisms (A study funded by the public-private infrastructure assistance facility - PPIAF) World Bank, Washington D.C.

World Bank (2006). Energy sector reform and the pattern of the poor: energy use and supply, a four country study: Botswana, Ghana, Honduras and Senegal. ESMAP, The World Bank, Washington D.C.

Zarnikau, J., Partridge, I., Dinning, J. and Robles, D. (2013). Will the SIEPAC Transmission Project Lead to a Vibrant Electricity Market in Central America? New Opportunities for Central America. International Association for Energy Economics, Fourth Quarter 2013, pp. 29-30. 
